\title{
PENINGKATAN PENGUASAAN KOSAKATA ANAK USIA 4-5 TAHUN MELALUI KEGIATAN BERMAIN KARTU BERGAMBAR
}

\author{
Lathipah Hasanah, S.Pd.,M.Pd \\ STAI Bani Saleh \\ latifahasanah@yahoo.com
}

\begin{abstract}
Penelitian ini bertujuan untuk meningkatkan penguasaan kosakata anak usia 4-5 tahun melalui kegiatan bermain kartu bergambar. Penelitian ini dilaksanakan di TK Al-Ikhlas Bekasi pada bulan April-Mei 2016. Metode yang digunakan adalah penelitian tindakan kelas yang dilakukan melalui dua siklus, siklus terdiri atas perencanaan (planning), tindakan (acting), pengamatan (observing), dan refleksi (reflecting). Subjek penelitian adalah anak TK A di TK Al-Ikhlas yang mempunyai masalah dalam penguasaan kosakata sebanyak 9 orang. Analisis data diperoleh dari hasil perbandingan antara penguasaan kosakata sebelum dan sesudah pelaksanaan tindakan. Data pra intervensi, penguasaan kosakata anak sebesar $37.5 \%$ masih kurang, di akhir siklus 1 penguasaan kosakata anak meningkat menjadi $58.75 \%$, dan di akhir siklus 2 penguasaan kosakata anak meningkat menjadi $81.1 \%$. Hasil akhir dari keseluruhan analisis persentase data adalah peningkatan sebesar $43,6 \%$.
\end{abstract}

Kata Kunci : Penguasaan Kosakata Anak Usia 4-5 Tahun Melalui Kegiatan Bermain Kartu Bergambar.

The purpose of this research is to improve the vocabulary mastery of children aged 4-5 years through picture cards playing activities in Al-Ikhlas Kindergarten, Bekasi conducted April to May 2016. The method used was classroom action research that was done by two cycle consisting of planning, acting, observing, and reflecting. The research subject were kindergarten children group A who had problem in mastery vocabulary as many as 9 childrens. The analysis data was obtained from the comparison between children vocabulary mastery before and after implemetation of the action. The result shows show that the data obtained in the pre-intervention vocabulary mastery of a child with a score $37.5 \%$ is still lacking, then after a given action on a cycle I, the obtained score of $58.75 \%$, but after a given action on a cycle II, vocabulary mastery of children up to $81 \%$. The final result from the overall analysis of data percentage was increase up to $43,6 \%$.

Key Word: Vocabulary Mastery Children of Age 4-5 Years Old Through Picture Cards Playing Activities. 


\section{PENDAHULUAN}

Kosakata merupakan salah satu unsur penting dalam bahasa. Kosakata memegang peranan penting dalam komunikasi, terlebih secara oral. Orang dewasa di sekitar anak perlu melatih dan memperkenalkan kosakata sebanyak-banyaknya kepada anak. Vallete (1977:87) mengungkapkan. Kemampuan untuk memahami bahasa tergantung pada pengetahuan kosakatanya. Akan tetapi mempunyai perbendaharaan kosakata saja belum cukup jika tidak disertai dengan pemahaman dari kosakata tersebut.

Sekolah khususnya Taman Kanak-kanak tertera dalam Peraturan Pemerintah Republik Indonesia Nomor 27 tahun 1990 (2001:1) menjelaskan pendidikan prasekolah yang memiliki tujuan untuk meletakkan dasar perkembangan sikap, pengetahuan, keterampilan dan daya cipta anak didik di dalam menyesuaikan dirinya dengan lingkungan. Pendidikan prasekolah tempat dimana anak-anak dapat berinteraksi dengan orang-orang yang baru dikenalnya, baik orang yang lebih muda, sebaya, lebih tua ataupun orang dewasa lainnya. Hal ini dapat membantu proses penguasaan kosakata pada anak. Untuk melatih anak berkomunikasi, guru dituntut kreatif melakukan kegiatan pembelajaran yang memungkinkan anak dapat berinteraksi dengan teman dan orang lain sebagai sarana mengungkapkan ide, perasaan, dan emosinya.

Bermain merupakan hak anak yang harus dipenuhi. Sebagaimana yang tertera pada Undang-undang pelindungan anak No. 23 Tahun 2002 Bab III tentang Hak dan Kewajiban Anak pasal 11 (2005:8) bahwa "Setiap anak berhak untuk beristirahat dan memanfaatkan waktu luang, bergaul dengan anak sebayanya, bermain berkreasi sesuai dengan bakat dan minatnya dan tingkat kecerdasannya demi pengembangan diri. Dalam hal ini berarti ketika memberikan stimulasi, orang dewasa di sekitar anak perlu memperhatikan kebutuhan dasar anak dengan memperhatikan minat anak dan memberikan stimulasi melalui permainan.

Kartu bergambar merupakan salah satu media visual yang dapat memberikan manfaat kepada anak sebagai cara dalam memperkenalkan simbol, warna, kata-kata dan meningkatkan penguasaan kosakata seperti mengenalkan kata benda yang ada di sekitar, kata, sifat, dan kata kerja sehari-hari. Sebagai media visual, kartu bergambar berfungsi sebagai sarana dalam menyampaikan pesan atau materi dalam kegiatan pembelajaran. 
Gambar dapat memberikan nilai yang sangat berarti, terutama dalam membentuk pengertian baru dan untuk memperjelas pengertian baru. Penggunaan kartu bergambar dapat menimbulkan daya tarik tersendiri bagi anak, merangsang minat anak sehingga anak lebih senang mengikuti kegiatan bermain sambil belajar di sekolah.

Penelitian ini diharapkan dapat meningkatkan penguasaan kosakata anak usia 45 tahun di Taman Kanak-kanak Kelompok A Al-ikhlas Bekasi melalui kegiatan bermain kartu bergambar. Penguasaan kosakata dalam penelitian ini adalah kemampuan anak dalam memahami dan menggunakan jenis kata dengan tepat baik lisan maupun tulisan. Indikator penguasaan kosakata 4-5 tahun yang akan diamati dibatasi pada (1) penguasaan kosakata anak secara aktif-produktif atau menggunakan kata dan (2) penguasaan kosakata anak secara pasif-reseptif atau memahami kata.

\section{Kajian Pustaka}

\section{Penguasaan Kosakata Anak Usia 4-5 Tahun}

Pengembangan kemampuan berbahasa merupakan salah satu pengembangan yang paling penting pada usia awal pertumbuhan anak. Perkembangan bahasa erat kaitannya dengan perkembangan anak secara keseluruhan baik dari segi kognitif, sosial, dan emosi. Sebagai alat ekspresi, anak belajar menggunakan bahasa pikirannya melalui bahasa verbal, untuk itu anak membutuhkan sejumlah kosakata yang cukup untuk dapat mengungkapkan apa yang ada di dalam pikirannya.

Penguasaan tidak terlepas dari pengetahuan seseorang terhadap apa yang sedang dipelajari. MacTurck dan Morgan (1995:283) menyatakan “mastery is great skillfulness and knowledge of some subject or activity”. Penguasaan berarti pengetahuan dan kecakapan dalam melakukan suatu aktivitas. Hal ini berarti seseorang dapat dikatakan menguasai ketika ia memiliki pengetahuan yang baik dalam dirinya lalu dapat mengaplikasikan pengetahuan tersebut dalam bentuk kegiatan atau aktivitas.

Jalongo (2007:47) mengungkapkan kosakata merupakan kata-kata yang terdapat dalam suatu bahasa. "vocabulary consists of the words we must know in order to communicate affectively”. Kosakata terdiri dari kata-kata yang kita ketahui dalam 
komunikasi secara efektif. Seseorang menggunakan kosakata untuk berkomunikasi dengan orang lain. Melalui kosakata, seseorang dapat menerima informasi, mengemukakan idenya dan menyalurkan emosinya.

Dalam mempelajari bahasa, faktor yang harus dikuasai adalah kosakata (vocabulary). Tanpa mempelajari serta memahami kosakata, seseorang tidak akan mampu mengerti apa yang ia baca serta apa yang oranglain katakan padanya. Darjowidjojo (2003:43) mengungkapkan penguasaan seseorang tentang kosakata dapat dikatakan sebagai cerminan dari kemampuan berbahasanya secara keseluruhan. Kemampuan anak dalam menguasai bahasa tidak terlepas dari penguasaan kosakatanya. Penguasaan kosakata yang merupakan bagian dari penguasaan bahasa dibedakan dalam penguasaan aktif-produktif dan pasif-reseptif. Penguasaan kosakata tersebut perlu dikuasai anak, karena dapat mempermudah anak dalam menggunakan serta memahami kata.

Dalam proses pembelajaran kosakata, diharapkan anak memahami dan mempergunakan kata tersebut dalam berbagai bentuk dan situasi. Kosakata secara pasif-reseptif dan aktif-produktif sangat berkaitan dengan bagaimana anak menggunakan dan memahami kata-kata. Penguasaan kosakata juga dijelaskan secara detail oleh Almeida (2001:4),

The receptive, children can learn some word meanings after only one or two exposures if the words is paired with a concrete object, an action, or a brief explanation. The productive use of new language, children begin to combine phrases they have learned and names of objects to make sentences.

Berdasarkan pemaparan tersebut, dapat diartikan bahwa, penggunaan secara reseptif, anak-anak belajar tentang beberapa arti kata dan menghubungkannya dengan objek yang konkret, melakukan tindakan, atau memberikan penjelasan singkat. Penggunaan bahasa produktif, yaitu anak-anak mulai belajar untuk menggabungkan frase dan membuat kalimat dari nama objek.

Penguasaan kosakata berkaitan erat dengan bagaimana anak menggunakan dan menguasai kosakata tersebut. Orang dewasa di sekitar anak perlu berperan aktif dalam mengembangkan penguasaan kosakata anak. Dalam mengembangkan penguasaan 
kosakata anak usia dini tidak terlepas dari penentuan kosakata apa saja yang sesuai dengan anak usia dini itu sendiri. Untuk itu, perlu diuraikan mengenai kata-kata yang relevan dan sesuai untuk anak usia dini. Menurut Suhartono (2005:194) uraian kosakata erat kaitannya dengan jenis kata. Jenis kata menurut pendapat Keraf yaitu kata-kata yang terbagi menjadi empat jenis, yaitu: kata benda, kata kerja, kata sifat, dan kata tugas. Jenis-jenis kata tersebut dapat memperkaya kosakata yang diperlukan anak untuk berkomunikasi sehari-hari. Adapun lingkup kosakata yang dapat diucapkan anak menyangkut warna, ukuran, bentuk, rasa, kecantikan, kecepatan, suhu, perbedaan, perbandingan jarak, dan permukaan.

Sudono (2000:16) memaparkan kosakata sangat diperlukan oleh anak sejak dini, hal ini berpengaruh terhadap kemampuan anak dalam berkomunikasi. Kosakata yang tepat berasal dari lingkungan terdekat dan dapat dikembangkan sedemikian rupa sehingga tidak membosankan bagi anak. Dalam perkembangan selanjutnya penguasaan kosakata oleh anak tidak hanya apa yang didengar dari orangtua, tetapi juga dari orang lain. Anak akan tumbuh dan berkembang dalam keluarga dan lingkungan sekitar. Pergaulan dengan teman-teman bermain juga turut memperluas perbendaharaan kosakata anak.

Usia 4-5 tahun adalah anak yang pada umumnya berada pada masa prasekolah. Taman kanak-kanak atau pendidikan prasekolah merupakan wahana yang sangat penting dalam mengembangkan bahasa anak. Hal ini berarti anak telah dapat mengungkapkan keinginannya, penolakannya, maupun pendapatnya. Anak memperoleh bahasa dari lingkungan keluarga, dan dari lingkungan tetangga. Melalui bahasa yang mereka miliki, perkembangan kosakata akan berkembang dengan cepat sebagaimana dikemukakan Sroufe (2011:74) "children vocabularies grew duite quikcly after they begin to speak.". Pertambahan kosakata anak akan bertambah sangat cepat setelah mereka mulai berbicara. Hal ini dapat dipahami karena anak akan menggunakan arti bahasa dari konteks yang digunakannya.

Anak usia 4-5 tahun sudah dapat belajar menjadi pendengar yang baik dan sudah dapat menggunakan kata-kata dengan tepat dalam berkomunikasi. Penguasaan kosakata anak usia 4-5 tahun menurut Jalongo (2007:74), 
Children can learn as many as 1400-1600 words. Child seeks ways to correct misunderstandings, begins to adjust speech to listener's information needs, disputes with peers can be resolved with words and invitations to play are more common.

Anak usia 4-5 tahun memiliki perbendaharaan 1400-1600 kata. Anak mencari cara untuk memperbaiki kesalahpahaman, mulai belajar menjadi pendengar yang baik, perselisihan dengan teman sebaya dapat diselesaikan dengan menggunakan kata-kata dan mereka dapat bermain bersama.

Berdasarkan pemaparan teori di atas terkait karakteristik anak usia 4-5 tahun, dapat dideskripsikan bahwa anak usia 4-5 tahun merupakan anak yang sudah memasuki jenjang prasekolah. Perkembangan kosakata anak sangat pesat. Anak sudah mampu menggunakan bahasa lisan dengan susunan kalimat yang baik. Anak sudah memiliki perbendaharaan kata yang cukup banyak dan sudah bisa melakukan percakapan sehari-hari dengan orang sekitar. Adanya interaksi dengan masyarakat memungkinkan anak untuk meniru kata dari orang lain dan mengucapkannya sehingga perbendaharaan kosakata anak semakin bertambah.

\section{Hakikat Kegiatan Bermain Kartu Bergambar}

Bermain merupakan salah satu cara belajar dalam pembelajaran pada anak usia dini. Bermain dapat mengembangkan kreativitas, minat, dan bakat secara optimal. Hal ini dikarenakan melalui bermain anak dapat menggunakan seluruh panca indera yang dimilikinya dan juga kemampuan bersosialisasi terhadap anak lain. Melalui bermain, anak usia dini mampu bereksplorasi berbagai kemungkinan dengan teman sebayanya.

Stone (1993:4) mengungkapkan bermain dapat membuat kereativitas anak berkembang. "play provides many opportunities for children to create, invent, and design as they build, draw, and dramatize. Play is a natural avenue for expression of creativity”. Bermain menyediakan banyak sekali kesempatan untuk anak menciptakan sesuatu, mereka dapat merancang dan membangun sesuatu, dan mendramatisasi. Bermain merupakan sebuah cara untuk berekspresi dan berkreativitas. Melalui bermain, anak tidak hanya memperoleh kesenangan, namun anak dapat belajar memperoleh suatu keterampilan yang dapat membantu anak dikehidupan selanjutnya. 
Anak usia dini dapat belajar dengan baik apabila belajar sesuai dengan tahap perkembangan, tingkatan usia dan kebutuhan anak. Selain itu juga harus memungkinkan anak dalam melakukan kegiatan sambil bermain. Piaget (2000:24) mengemukakan tahapan bermain sebagai berikut: (1) Sensory motor play, (2) Symbolic atau make believe play, (3) Social play game with rules, (4) Games with rules and sports. Berdasarkan uraian tersebut dapat dipahami bahwa tahapan bermain yang dikemukakan piaget dapat diajarkan guru sesuai dengan tahapan perkembangan dan usia anak.

Tahapan pertama, sensory motor play. Anak usia 3/4 bulan sampai $1 / 2$ tahun berada pada tahap ini. Gerakan atau tindakan yang dilakukan anak sebelum usia 3-4 bulan belum dapat dikatakan bermain. Pada usia ini anak hanya melakukan gerakan atau tindakan pengulangan dari kegiatan yang dilakukan sebelumnya.

Tahapan kedua, symbolic or make believe play. Pada tahap ini, terjadi antara usia 2-7 tahun. Anak usia 2-7 tahun mulai melukiskan dunia dengan kata-kata dan gambar. Anak mengungkapkan rasa ingin tahunya dengan kata-kata dan gambar. Selain itu juga anak senang bertanya dan menjawab pertanyaan. Pada tahap ini anak mulai bermain simbolik. Anak menganggap benda-benda disekitarnya sebagai alat permainannya.

Tahapan ketiga, social play with rules. Anak usai 8-11 tahun sudah mulai bermain dengan peraturan. Sejak usia ini anak lebih sering terlibat dalam kegiatan games with rules. Games ini adalah kegiatan-kegiatan yang dilakukan untuk memperoleh kenikmatan yang melibatkan aturan dan seringkali kompetisi dengan satu orang lebih. Pada tahap ini anak mulai memahami bahwa peraturan dapat disepakati bersama dengan pemain.

Tahap keempat, games with rules and sports. Permainan dengan aturan merupakan permainan yang melibatkan aturan-aturan tertentu dan seringkali berkompetensi dengan satu orang atau lebih. Kegiatan anak dalam permainan ini lebih banyak dikendalikan oleh aturan permaninan. Namun, anak akan tetap merasa senang dan terpacu untuk mencapai hasil sebaik-baiknya. 
Dapat dipahami bahwa dalam sebuah permainan memiliki tahapan-tahapan tertentu yang perlu dilewati anak. Tahapan kegiatan bermain terdiri dari tingkat yang sederhana sampai dengan tingkat yang paling tinggi. Dapat dipahami bahwa minat anak usia 4-5 tahun berada pada tahapan kedua yaitu symbolic or make believe play dimana anak mulai melukiskan keinginannya dengan kata-kata dan gambar.

Berdasarkan beberapa uraian yang diuraikan oleh para ahli, dapat dideskripsikan bahwa bermain memiliki manfaat, ciri-ciri, serta tahapan tersendiri. Melalui bermain anak akan menemukan pengalaman-pengalaman baru dengan cara memanipulasi benda, alat, berinteraksi dengan anak lain serta mulai membangun pengetahuan yang lebih luas tentang dunia sekitar anak. Bermain menyediakan pengalaman bagi anak untuk mengembangkan pengetahuan tentang diri sendiri, orang lain, dan lingkungan sekitar. Selain itu bermain memberikan ruang dan waktu bagi anak untuk berinteraksi dengan orang lain.

Kartu bergambar merupakan alat bantu visual yang banyak digunakan oleh guru dalam pembelajaran untuk meningkatkan penguasaan kosakata anak. Kartu bergambar merupakan salah satu media pembelajaran yang dapat memberikan manfaat kepada anak sebagai sebuah cara dalam memperkenalkan simbol, kata-kata dan meningkatkan penguasaan kosakata seperti mengenalkan kata benda maupun kata kerja yang ada di sekitar anak. Berikut ini merupakan beberapa pendapat para ahli mengenai kartu bergambar.

Indriana mengemukakan (2008:68) flash cards adalah media pembelajaran dalam bentuk kartu bergambar yang ukurannya seukuran post cards sekitar 25 x 30 cm. Gambar yang ditampilkan dalam kartu tersebut adalah gambaran tangan atau foto, atau gambar atau foto yang sudah ada dan ditempelkan pada lembaran kartu-kartu tersebut. Kartu bergambar dapat digunakan dalam pembelajaran sesuai dengan tema. Misalnya ketika sedang mempelajari tema binatang, guru dapat menggunakan kartu bergambar untuk menjadi media dalam mengenalkan macam-macam binatang. Anak tidak hanya diperlihatkan jenis-jenis binatang yang sudah mereka ketahui, namun guru dapat memperkenalkan binatang-binatang langka yang belum anak ketahui, sehingga perbendaharaan anak tentang nama-nama binatang dapat bertambah. 
Philips mengemukakan (2003:69) kartu bergambar merupakan cara yang tepat dalam memperkenalkan kosakata baru pada anak. "flash cards (picture cards) are an invaluable way of introducing and revising vocabulary and can also be used to drill simple structure and function". Pernyataan tersebut dapat diartikan secara bebas bahwa flash cards atau kartu bergambar adalah sebuah cara untuk memperkenalkan kosakata dan juga dapat digunakan untuk mengetahui struktur dan fungsi sederhana. Flash cards tidak hanya digunakan untuk memperkenalkan kosakata, namun dapat digunakan untuk mempelajari hal-hal yang lebih kompleks.

Melalui penggunaan media kartu bergambar dapat membuat pembelajaran menjadi menarik. Ketika anak mempelajari bahasa khususnya perbendaharaan kata, tidak dilakukan hanya secara verbal atau mendengarkan cerita dari guru. Hal ini membuat anak menjadi bosan dan tidak bersemangat. Melalui kartu bergambar, anak dapat belajar tidak hanya dengan mendengarkan namun dapat melakukan dan mendemonstrasikan.

\section{METODELOGI PENELITIAN}

Metode yang digunakan adalah penelitian tindakan (action research). Penelitian tindakan atau yang lebih dikenal dengan action research, pada prinsipnya dimaksudkan untuk mengatasi suatu permasalahan yang terdapat di dalam kelas. Hal ini ditegaskan oleh McNiff dalam Arikunto (2006:106) bahwa dasar utama dari metode ini adalah untuk perbaikan dan peningkatan layanan profesional pendidik dalam menangani proses belajar mengajar dengan melakukan berbagai tindakan alternatif dalam memecahkan persoalan pembelajaran. Dalam hal ini peneliti atau guru melakukan sesuatu yang arah dan tujuan penelitiannya sudah jelas, yaitu demi kepentingan peserta didik dalam memperoleh hasil belajar yang memuaskan.

Subjek dalam penelitian ini adalah anak usia 4-5 Tahun di Taman Kanak-kanak Al-ikhlas Bekasi. Subjek penelitian yang dipilih adalah berdasarkan kriteria anak yang penguasaan kosakatanya rendah. Pemilihan subjek penelitian dilakukan pada 15 orang anak, pemilihan anak dilakukan pada pra penelitian melalui observasi kegiatan pembelajaran sebanyak tiga kali pertemuan dan hasil rekomendasi dari guru kelas, 
maka teridentifikasi 9 anak yang penguasaan kosakatanya rendah dan masih perlu ditingkatkan.

Penelitian tindakan ini dilaksanakan di Taman Kanak-kanak Kelompok A AlIkhlas Bekasi yang beralamat di Jl. Nakula 6C Jakasetia, Bekasi Selatan. Waktu penelitian ini dilaksanakan pada tahun ajaran 2016, yaitu pada bulan April sampai dengan Mei 2016. Pada bulan tersebut kegiatan pembelajaran anak-anak di kelas TK A sedang berjalan efektif. Sehingga memungkinkan peneliti untuk meneliti dan memperoleh data penelitian.

Teknik pengumpulan data yang dilakukan pada penelitian ini adalah teknik pengumpulan data secara non tes dan tes. Teknik pengumpulan non tes ini terdiri dari observasi, wawancara, dan dokumentasi terhadap kegiatan yang sedang berlangsung, berkenaan dengan kegiatan pembelajaran di dalam kelas, sedangkan tekhnik tes yang dilakukan adalah tes perbuatan.

Data yang digunakan dalam penelitian tindakan ini adalah data kuantitatif dan kualitatif. Analisis data kuantitatif dilakukan secara terus menerus setiap siklus dengan persentasi kenaikan. Analisis data kualitatif dilakukan dengan cara menganalisis data dari hasil catatan lapangan, catatan wawancara dan catatan dokumentasi selama penelitian. Teknik analisis data yang digunakan bertujuan untuk mengetahui pengaruh pemberian tindakan kegiatan bermain kartu bergambar terhadap peningkatan penguasaan kosakata anak usia 4-5 tahun.

\section{HASIL PENELITIAN}

Data penelitian ini dideskripsikan dalam bentuk penyajian data secara kuantitatif dan kualitatif. Data kuantitatif untuk melihat persentase kenaikan pada setiap siklusnya. Sedangkan data kualitatif untuk menganalisis data yang diperoleh melalui CL, CW, dan CD di lapangan. Berikut ini merupakan deskripsi data kuantitatif mengenai penguasaan kosakata anak usia 4-5 tahun melalui kegiatan bermain kartu bergambar. 
Tabel. 1

Data Hasil Penguasaan Kosakata Anak

\begin{tabular}{|l|l|l|l|}
\hline Pra Siklus & Siklus 1 & Siklus 2 & Peningkatan \\
\hline $37,5 \%$ & $58,75 \%$ & $81,1 \%$ & $43,6 \%$ \\
\hline
\end{tabular}

Berdasarkan hasil analisis data pada siklus 1, persentase kenaikan diperoleh sebesar 21,25\% dan siklus 2 persentase kenaikan diperoleh sebesar 21,35\%. Jadi persentase kenaikan seluruhnya dari pra siklus hingga siklus 2 sebesar 43,6\%. Hal ini memiliki makna bahwa telah terjadi peningkatan persentase yang signifikan dari penguasaan kosakata anak pada pra penelitiam hingga siklus 2 .

Hasil analisis data kualitatif membuktikan bahwa kegiatan bermain kartu bergambar) dapat meningkatkan kemampuan anak dalam penguasaan kosakata secara aktif-produktif maupun pasif-reseptif. Melalui kegiatan bermain kartu bergambar, dapat membangun pemahaman anak mengenai tema yang akan dipelajari. Anak lebih bersemangat ketika pembelajaran karena dilakukan melalui sebuah permainan, anak mulai terbiasa dengan peraturan dalam bermain, anak terbiasa untuk bertanya dan mengungkapkan pendapatnya, serta anak dapat belajar dengan cara menemukan sendiri melalui kegiatan bermain yang menyenangkan. Kegiatan bermain kartu bergambar membuat anak belajar untuk menemukan sendiri serta terlibat secara aktif dalam proses pembelajaran. Selain itu dapat memberikan pengalaman baru dan berharga pada anak, rasa ingin tahu dan perhatian anak pun dapat difasilitasi. Berdasarkan hasil pengamatan, melalui kegiatan bermain ini, anak mampu menunjukkan dan menyebutkan benda-benda yang dimaksud berdasarkan cerita guru, anak juga terlihat mulai mampu untuk mengidentifikasi gambar serta menyebutkan kata kerja, kata benda, dan kata sifat berdasarkan gambar, serta anak mampu bercerita dengan menggunakan kartu bergambar. 


\section{KESIMPULAN}

Berdasarkan hasil analis data pada Prapenelitian didapat persentase sebesar $37,5 \%$, sedangkan pada siklus I didapat persentase sebesar 58,75\%. Dari data tersebut dapat dikatakan bahwa persentase dari Prapenelitian ke siklus I mengalami peningkatan pada indikator secara keseluruhan sebesar 21,25\%. Sebagaimana disampaikan pada interpretasi hasil analis bahwa penelitian ini dikatakan berhasil jika adanya peningkatan sebesar 35\%, maka pada penelitian siklus I ini belum dapat dikatakan berhasil karena persentase kenaikan yang didapat sebesar 21,5\% untuk seluruh indikator.

Terlihat adanya peningkatan penguasaan kosakata anak usia 4-5 tahun melalui pemberian tindakan berupa kegiatan bermain kartu bergambar. Kegiatan bermain kartu bergambar disertai dengan tema yang beragam serta adanya variasi kegiatan di setiap pertemuannya. Kegiatan bermain kartu bergambar juga membuat anak belajar untuk menemukan sendiri serta terlibat secara aktif dalam proses pembelajaran. Berdasarkan hasil observasi dalam bentuk catatan lapangan, catatan dokumentasi, dan catatan wawancara dapat dilihat bahwa kegiatan bermain kartu bergambar dapat meningkatkan penguasaan kosakata anak usia 4-5 tahun di TK A Al-Ikhlas Bekasi.

Penerapan kegiatan bermain kartu bergambar di sekolah dapat digunakan oleh guru dan pihak sekolah sebagai alternatif dalam meningkatkan penguasaan kosakata anak. Hal ini dikarenakan pada pelaksanaanya, kegiatan bermain kartu bergambar mampu memberikan pengalaman baru dan berharga pada anak, rasa ingin tahu dan perhatian anak pun dapat difasilitasi, sehingga anak dapat terlibat aktif dalam kegiatan pembelajaran yang sesuai dengan tahap perkembangannya.

Kegiatan bermain kartu bergambar pada akhirnya dapat memberikan hasil yang baik pada penguasaan kosakata anak, diantaranya penguasaan kosakata secara pasifreseptif dan aktif-produktif. Pemberian kegiatan bermain kartu bergambar disertai dengan tema yang beragam serta adanya variasi kegiatan membuat anak ingin kembali mendapatkan pengalaman langsung dalam bermain kartu bergambar. Semakin banyak pengalaman yang diberikan pada anak dalam bermain kartu bergambar, maka penguasaan kosakata anak semakin meningkat. 


\section{DAFTAR PUSTAKA}

Akbar Reni, 2001, Psikologi Perkembangan Anak. Jakarta: Grasindo.

Almeida, Paul E, 2001, Preschool Curriculum. New Jersey Avenue: Washington DC.

Arikunto, Suharsimi, dkk, 2006, Penelitian Tindakan Kelas. Jakarta: Bumi Aksara.

Dardjowidjojo, Soenjono, 2003, Psingolinguistik Pemahaman Bahasa Manusia. Jakarta: Yayasan Obor Indonesia.

Jalongo, Mary Renck, 2007, Early Childhood Language Arts. USA: Pearson Education.

MacTruck, Robert H. and George A. Morgan, 1995, Mastery Motivation Conceptualizations and Application. NNew Jersey: Ablex Publishing Corporation.

Peraturan Pemerintah No. 19 tahun 2005 tentang standar nasional pendidikan pasal 17 ayat 1 .

Philips, Sarah, 2003, Young Learners. Oxford University.

Sudono, Anggani, 2000, Sumber Belajar dan Alat Permainan. Jakarta: Grasindo

Suhartono, 2005, Pengembangan Keterampilan Berbicara Anak Usia Dini. Jakarta: Depdiknas.

Stone, Sandra J, 1993, Playing a Kid's Curriculum. USA.

Susanto, Ahmad, 2011, Perkembangan Anak Usia Dini. Jakarta: Kencana.

Vallete, Rebeca, 1977, Modern Languange Testing. New York: Harcourt Jovanovich 